This item was submitted to Loughborough's Research Repository by the author.

Items in Figshare are protected by copyright, with all rights reserved, unless otherwise indicated.

\title{
Immigrant sentiment and labour market vulnerability: economic perceptions of immigration in dualized labour markets
}

PLEASE CITE THE PUBLISHED VERSION

https://doi.org/10.1057/s41295-019-00194-1

\section{PUBLISHER}

Palgrave Macmillan UK

\section{VERSION}

AM (Accepted Manuscript)

\section{PUBLISHER STATEMENT}

This is a post-peer-review, pre-copyedit version of an article published in Comparative European Politics. The definitive publisher-authenticated version KEVINS, A. and LIGHTMAN, N., 2019. Immigrant sentiment and labour market vulnerability: economic perceptions of immigration in dualized labour markets. Comparative European Politics, 18, pp.460-484, https://doi.org/10.1057/s41295-019-00194-1 is available online at: https://link.springer.com/article/10.1057/s41295-019-00194-1.

\section{LICENCE}

CC BY-NC-ND 4.0

\section{REPOSITORY RECORD}

Kevins, Anthony, and Naomi Lightman. 2019. "Immigrant Sentiment and Labour Market Vulnerability: Economic Perceptions of Immigration in Dualized Labour Markets”. Loughborough University. https://hdl.handle.net/2134/9976301.v1. 


\title{
Immigrant Sentiment and Labour Market Vulnerability: \\ Economic Perceptions of Immigration in Dualized Labour Markets ${ }^{1}$
}

\author{
Anthony Kevins, $\mathrm{PhD}$ \\ Marie Curie Research Fellow \\ Utrecht University School of Governance \\ a.v.kevins@uu.nl \\ anthonykevins.github.io \\ Naomi Lightman, PhD \\ Assistant Professor \\ Department of Sociology, University of Calgary \\ naomi.lightman@ucalgary.ca \\ naomilightman.wordpress.com
}

Published in Comparative European Politics: $\underline{\text { https://doi.org/10.1057/s41295-019-00194-1 }}$

Abstract: Recent years have seen an increase in concerns that labour market vulnerability and national economic performance might be interacting to foment more polarized opinions about immigration. This article uses European Social Survey and EU-SILC data from 23 countries to explore this potential relationship, examining attitudes about the economic impact of immigration. In doing so, it seeks to investigate how the link between labour market vulnerability and anti-immigrant sentiment may be shaped by both resource scarcity (in the economy as a whole) and job scarcity (on the labour market). Findings from the analysis are twofold. First, labour market vulnerability is indeed correlated with more negative beliefs about the economic contribution of immigrants, even controlling for related factors such as education and contract type. Second, this effect is moderated by GDP per capita (though not unemployment rates), with labour market insiders and outsiders holding more distinct attitudes in higher GDP countries; thus, although attitudes towards the economic contribution of immigrants are generally more negative in poorer countries, labour market vulnerability contributes to greater opinion polarization in stronger economies. It is therefore resource availability in the economy, rather than on the labour market, that appears to be crucial.

Key words: labour market vulnerability; anti-immigrant sentiment; public opinion; GDP; unemployment.

\footnotetext{
${ }^{1}$ This paper benefited from helpful feedback provided at the Symposium on Challenges to European Integration: Welfare States and Free Movement in the EU (at Leiden University) and the Annual Meeting of the European Political Science Association (in Belfast, Northern Ireland), including from Alexandre Afonso and Dalston Ward.
} 
Anti-immigrant sentiment has long been a significant feature of public opinion, and anxieties about the economic effects of immigration are a mainstay of these attitudes. Such worries take many forms, including concerns about immigrants "stealing jobs", driving down wages, and putting undue pressure on public expenditure (Dancygier and Donnelly, 2012; MalchowMøller et al., 2008; Donnelly, 2016); yet they all suggest at least a superficial fixation with the economic consequences of immigration, and one which recurs frequently in both the media and the political arena. Indeed, fears about the negative economic effects of immigrants have been found to play an important role in generating broader anti-immigrant attitudes and bolstering support for populist and radical right-wing parties (e.g. Scheve and Slaughter, 2001; Cutts et al., 2011). This article thus sets out to investigate the factors shaping these attitudes.

There are good reasons to think that labour market experiences may be central to understanding beliefs about the economic consequences of immigration. Past research has highlighted the effects of individual-level attributes such as education and skill level on immigrant sentiment (e.g. Paas and Halapuu, 2012; Facchini and Mayda, 2012) - but studies have had a much harder time addressing the impact of respondents' positions on the labour market (c.f. Hainmueller et al., 2015; Hainmueller and Hopkins, 2014). Insofar as education and skill-levels are not perfect substitutes for vulnerability on the labour market (see Häusermann et al., 2014), this is a major shortcoming. To address this limitation, this article employs Schwander and Häusermann's (2013) continuous measure of labour market vulnerability to examine whether and to what extent "outsiderness" affects concerns about the economic consequences of immigration. This approach allows us to study the impact of outsiderness while controlling for related factors such as education and momentary contract status; in the absence of cross-national panel data, the measure thus presents a unique opportunity to tease out the consequences of these related yet conceptually distinct factors. 
Yet the relationship between labour market vulnerability and anti-immigrant sentiment almost certainly varies by country as well (e.g. Sides and Citrin, 2007; Polavieja, 2016). Given our expectation that outsiderness matters for reasons tied to (perceived) economic competition, we home in on the potential role of economic context. Past research suggests that strong economies generate more positive attitudes toward immigrants - though there is some debate as to whether it is overall affluence (i.e. GDP per capita) or labour market performance (i.e. unemployment rates) that matters most (cf. Wilkes et al., 2008; Meuleman et al., 2009). We therefore examine how individual-level labour market outsiderness interacts with GDP per capita (adjusted for purchasing power) and the unemployment rate. This allows us to investigate how the link between labour market vulnerability and anti-immigrant sentiment may be shaped by resource scarcity (in the national economy as a whole) and job scarcity (on the labour market).

We conduct this analysis using data on 23 European countries from the European Union Statistics on Income and Living Conditions (EU-SILC) as well as the 2008 to 2014 waves of the European Social Survey. These data are ideal for our purposes, since they offer both the fine-grained occupational data required to measure labour market vulnerability and a multiwave survey item assessing perceptions of immigrants' economic contributions. Findings from the analysis are twofold. First, labour market vulnerability is indeed correlated with more negative beliefs about the economic contribution of immigrants, even controlling for related factors such as education and contract type. Second, this effect is moderated by general resource availability, with labour market insiders and outsiders holding more distinct attitudes in higher GDP countries. Specifically, we find that although attitudes towards the economic contribution of immigrants are generally more negative in poorer countries, individual labour market vulnerability contributes to greater opinion polarization in stronger economies. By contrast, we find no evidence to suggest that employment scarcity shapes the 
relationship between labour market vulnerability and beliefs about the economic contribution of immigrants. It is therefore resource availability in the economy as a whole, rather than simply on the labour market, that appears to moderate the effect of labour market vulnerability.

\section{Literature Review}

We begin by providing an overview of three bodies of literature that provide the background for our study, examining: (1) individual attitudes about the economic contribution of immigrants; (2) the relationship between national economic circumstances and immigrant sentiment; and (3) labour market dualization and precarity. Laying out the contours of these literatures allows us to then specify the hypotheses that this study will test.

\section{Individual Perceptions of the Economic Contribution of Immigrants}

The economic contribution of immigrants has been a subject of considerable (and often contentious) debate in the media, the political arena, and academia. Studies on the topic can broadly be divided into two theoretical camps. Those within a "closed-economy" framework predict that increased immigration leads to increased labour market competition and, ultimately, to declining wages among native-born populations (e.g. Borjas, 2003; Borjas, 2006). Under this framework, immigrants are presumed to price themselves downwards into employment in their new country of residence (a "race to the bottom"), in particular within the low-skilled, low-wage occupations where they are overrepresented (e.g. Hainmueller et al., 2015; Krings, 2009). By contrast, studies grounded within an "open-economy" framework presume that trade can offset any negative economic impacts of immigration, as 
the economy adjusts to immigrant inflows and goods are produced locally at lower cost (e.g. Card, 2001; Card et al., 2012; Ottaviano and Peri, 2012). This model posits that native-born wages, in general, will be unaffected by immigration, so long as the economy is not so large that a change in its output mix affects world prices (e.g. Dustmann et al., 2005; Gaston and Nelson, 2000).

Perceptions of immigration, however, may well be entirely disconnected from immigration's actual effects - and many citizens clearly worry that immigrants will take jobs away from the native-born, disproportionately hurt the economic opportunities available to the poor, and put undue pressure on public expenditures (Dancygier and Donnelly, 2012; Malchow-Møller et al., 2008). These perceptions have themselves been the focus of considerable research. In studies of anti-immigrant sentiment, economic self-interest, on the one hand, and symbolic prejudice and/or differences in cultural values and beliefs, on the other, are often treated as competing explanations (e.g. Facchini and Mayda, 2012; Sides and Citrin, 2007). Burns and Gimpel (2000), however, argue that the two explanations are likely complementary rather than contradictory. Supporting this supposition, Scheve and Slaughter (2001) and Mayda (2006) find evidence that both economic and non-economic factors influence attitudes towards immigration, rejecting a view that ideological considerations entirely shape attitudes toward the foreign-born.

A key potential mediator in this relationship is the native-born population's human capital or skill level, which numerous studies suggest impact individual perceptions of immigration. Low-skilled and low-educated native-born citizens, as well as those with lower economic security (i.e. "outsiders"), are most often found to harbour anti-immigrant attitudes and to favour reduced immigration (Paas and Halapuu, 2012; Facchini and Mayda, 2012). Hainmuller and Hiscox (2007), for example, find that higher educational attainment is associated with lower levels of racism, an increased commitment to cultural diversity, and an 
increased belief that immigration is economically beneficial. Ortega and Polavieja (2012) find that the degree of manual intensity within workers' occupations, along with education and ideology, play a role in determining individual attitudes toward immigration, while Pardos-Prado and Xena (2018) reveal that skill specificity (and hence a lack of occupational transferability) is an important predictor of anti-immigrant attitudes.

Yet there are strong reasons to believe that it is not just the skill level of the native-born population that matters: the skill composition of the immigrant population likely shapes attitudes about the economic contribution of immigrants as well (e.g. Mayda, 2006). Indeed, a number of contextual factors may well affect these beliefs, and the next section turns to consider the national-level economic characteristics that have been highlighted by past studies.

\section{Impact of National Economic Circumstances on Attitudes Towards Immigration}

Cross-national research demonstrates that national-level economic conditions, such as unemployment rates and affluence (i.e. GDP) have a positive association with changes in public opinion on a variety of issues ranging from social redistribution (Finseraas, 2009) to gender equality (Bergh, 2006). Similarly, a long line of scholars have suggested that attitudes towards immigration are shaped by national economic conditions (e.g. Kehrberg, 2007; Wilkes et al., 2008; Jackman and Volpert, 1996). In a systematic review of the literature on public opinions towards immigration, Hainmueller and Hopkins (2014), for example, find that most research suggests that sociotropic concerns about national-level impacts, be they cultural or economic, are the key factor shaping anti-immigrant sentiment.

Overall, the association between national economic circumstances and immigrant sentiment is believed to be a positive one: strong economies are thought to contribute to more positive 
attitudes toward immigrants; while poorer countries, as well as those experiencing recessions, generally have greater anti-immigrant sentiment and a higher perceived threat from foreigners (e.g. Zolberg, 1991; Burns and Gimpel, 2000). Although some scholars suggest that these effects vary by industry (e.g. Dancygier and Donnelly, 2012) or depend upon the presence of a far-right political party (Cochrane and Nevitte, 2014), the question is not whether economic circumstances matter, but how broadly. When it comes to determining which types of economic conditions matter, however, there is considerable debate.

Some studies focus on the level of wealth in society - typically measured by GDP (purchasing power parity) per capita (e.g. Schneider, 2008; Kaya and Karakoç, 2012) - while others argue that it is unemployment rates that should be central for anti-immigrant sentiment (e.g. Semyonov et al., 2006; Rustenbach, 2010). Either way, such research typically suggests that reduced resource competition in wealthier countries leads to more positive attitudes toward immigration (Pichler, 2010; Meuleman et al., 2009). According to this line of argument, when resources are more abundant, economic competition decreases, leading both immigrants and non-immigrants to feel as though there are sufficient resources for everyone; consequently, the native-born become more accepting of higher rates of immigration and feel more positive about the foreign-born (Wilkes et al., 2008; Chang and Kang, 2015).

In sum, it seems probable that national economic circumstances will interact with individuallevel characteristics to shape attitudes toward the economic contribution of immigrants. The final section of the literature review turns to consider the ways in which labour market vulnerability might be an important, and thus far underdeveloped, linkage between individual-level characteristics and the national economic context. 
A large body of literature has highlighted the potential importance of labour market dualization for a variety of preference and policy-based outcomes (e.g. Marx, 2014; Emmenegger et al., 2012; Kevins, 2017). Such research starts from the observation that there has been a growing divide in labour markets, with "insiders" benefiting from (traditional) higher quality employment while "outsiders" are forced to rely on temporary, part-time, and low paid work (e.g. Cranford and Vosko, 2006; Berger and Piore, 1980). This latter group, sometimes referred to as the "precariat" due to the precarious nature of their economic and social positions, is disproportionately made up of women, the young, immigrants, and racialized populations (e.g. Gash and McGinnity, 2007; Goldring and Landolt, 2012; Lightman and Gingrich, 2013).

In suggesting that labour market vulnerability (i.e. "outsiderness") may matter for attitudes toward the economic contribution of immigrants, it is essential to distinguish the concept from other related - yet distinct - individual-level characteristics. To begin, we note that outsiderness is not just another means to suggest that education and skill-level matter: as the literature on dualization makes clear, the distribution of labour market vulnerability does not simply reflect education levels (see Häusermann et al., 2014). Older industrial workers in Italy, for instance, may well be less represented in precarious employment than younger, more educated workers - while the opposite may be true, for example, in the United Kingdom. Thus, the distribution of risk of low-quality employment may differ considerably across countries, reflecting variations in labour markets and social norms.

At the same time, labour market precarity should also matter for reasons that are distinct even from momentary (un)employment status (see Kevins, 2018). First, rather than being a transitionary space leading to full-time work, precarious employment is typically followed by yet more precarity, with stints of unemployment in between (e.g. Gash and McGinnity, 2007; Goldring and Landolt, 2014). Second, even during periods of employment, precarious work 
has been connected to increased social exclusion, poor health, and decreased perceptions of fairness (D'Addio and Rosholm, 2005; Anderson, 2009; Lightman and Gingrich, 2013). Finally, those with atypical employment histories lack access to the generous welfare state benefits and stronger labour market protections that insiders are generally able to rely upon (e.g. Haüsermann and Schwander, 2012; Kevins, 2015).

Connecting the literature on dualization with research on immigrant sentiment leads us to develop the following four hypotheses. At the most basic level, we expect that increased outsiderness will be associated with more negative attitudes toward the economic contribution of immigrants (H1). The intuition here is that outsiders will view immigrants as disproportionately worsening their already weak labour market position (Dancygier and Donnelly, 2012; Malchow-Møller et al., 2008), whereas insiders will feel comparatively unthreatened. Resource competition (or the perception of such) is thus the key underlying mechanism for this relationship, with reduced access to welfare state benefits and labour market protections exacerbating economic vulnerability. For outsiders, then, the perceived individual-level economic threat that is posed by immigration will outweigh any potential macro-level economic benefits that immigration might have - whereas the opposite may be true for insiders.

In light of the literature on national economic factors, however, the relationship between outsiderness and attitudes toward the economic contribution of immigrants should also vary by country (e.g. Sides and Citrin, 2007; Polavieja, 2016). In particular, given that our individual-level hypothesis centres around the implications of (perceived) economic competition, we expect that resource scarcity at the national level is likely to interact with outsiderness. As laid out above, existing research suggests that this interaction might take several forms, with unemployment rates and wealth/prosperity (GDP per capita) potentially playing central roles (e.g. Kaya \& Karakoç, 2012; Rustenbach, 2010). 
On the one hand, the availability of jobs on the labour market may be the crucial metric. This expectation is driven by the assumption that the labour market is the most likely venue for the (perceived) resource competition between the native- and foreign-born populations. Immigrant groups may be denounced as unfair competitors (due to the perception that they are willing to work for lower wages and/or in less attractive jobs with fewer employment protections) and immigration may thus be viewed as a threat to employment access among the native-born (see, for example, Semyonov et al., 2006; Rustenbach, 2010). While past research has highlighted the importance of job scarcity for the native-born population as a whole, this sense of resource competition should be especially heightened among outsiders, as their position on the labour market is (by definition) less secure. Higher unemployment rates may thus increase the impact of labour market vulnerability on attitudes toward the economic contribution of immigrants (H2).

On the other hand, GDP per capita, as a proxy for the overall level of resources in a society (see, for example, Schneider, 2008; Kaya and Karakoç, 2012), might also structure the impact of outsiderness. This interactive relationship could take one of two forms. First, in lessdeveloped economies, the general population - not just outsiders - may experience a heightened sense of resource scarcity, leading both insiders and outsiders to feel economically threatened by immigrants; in stronger economies, however, these concerns may be limited to the more vulnerable segments of the labour market. In particular, given that labour market outsiders are likely subject to greater relative deprivation (compared to insiders) in wealthier economies, the experience of resource competition with immigrants may be more varied in these countries. We therefore expect that higher GDP per capita may be associated with a larger impact of outsiderness on attitudes toward the economic contribution of immigrants (H3). 
Alternatively, higher levels of GDP per capita might lead the citizenry as a whole to be less concerned about resource scarcity, in the process reducing the perceived economic threat from immigrants (see Wilkes et. al. 2008). Although this assumption ignores questions of resource distribution, it is broadly in keeping with past research suggesting that wealthier countries have lower levels of perceived immigrant threat (e.g. Pichler, 2010). Assuming that outsiders are disproportionately inclined to take anti-immigrant stances due to their precarious situation on the labour market, this suggests that the impact of outsiderness on anti-immigrant sentiment may decrease as GDP per capita increases (H4).

The remainder of this paper tests these four hypotheses, first laying out the setup of the study and then presenting our results.

\section{Data}

We carry out our main analysis using data from the European Social Survey (ESS, 2008; $2010 ; 2012 ; 2014)$. The ESS provides high quality survey data that includes a multi-wave question on the impact of immigration on the economy alongside fine-grained occupational data. The latter are based upon the International Standard Classification of Occupations (ISCO) codes - a requirement for the use of Schwander and Häusermann's (2013) occupation-specific approach to measuring labour market precarity. We restrict the study to the 2008-2014 survey waves since previous rounds do not include a standardized income measure (a key control in light of our central focus on outsiderness). ${ }^{i}$

The study incorporates survey data from the 23 European countries included in one or more of these survey waves. Appendix Table 1 lists the number of observations in each case, as well as by wave. The number of per wave respondents in our analysis varies from 315 (Italy, 2012) to 1484 (Germany, 2014), while the sample as a whole includes 57051 respondents. 


\section{Dependent Variable}

The selected dependent variable is intended to capture beliefs about the impact of immigrants on the economy. Specifically, respondents were asked "Would you say it is generally bad or good for [country] 's economy that people come to live here from other countries?"

Responses were recorded on an 11-point scale ranging from "bad for the economy" $(0)$ to "good for the economy" (10). Taking into account survey design weights, the mean response in the overall sample is 5.23, with a standard deviation of 2.36 (see Appendix Table 2). The country means vary considerably, however, ranging from 3.64 in Greece to 6.27 in Switzerland (see Figure 1 below).

Note that although this question asks respondents to expressly comment on the economic impact of immigrants, broader attitudes toward immigration likely colour these responses as well (e.g. Sniderman and Hagendoorn, 2007). Kehrberg (2015), for example, reports that responses to this item in the ESS are correlated with responses to similarly worded questions (posed immediately after the economy question) about the cultural and overall impact of immigration (with Pearson correlation coefficients of .61 and .65 respectively). Nevertheless, work using responses to these three items as dependent variables confirms meaningful variation among them (see Donnelly, 2016). Given our specific interest in the economic impact of immigration, we therefore opt to analyse responses to this question directly (rather than, for example, constructing an index using the three available items). Doing so allows us to minimize the relative effect of non-economic considerations on our outcome measure, though we also conduct sensitivity analysis with a modified dependent variable (see footnote 5 for further discussion). 


\section{Independent variables}

The key independent variable in our analysis is labour market vulnerability (i.e.

outsiderness), both on its own (in the first set of models) and in interaction with GDP per capita and the national unemployment rate (in the second set of models). In doing so, we extend existing research by looking expressly at labour market outsiderness rather than related factors such as education or momentary (un)employment status.

Our analysis therefore avoids the traditional approach in the literature on dualization, which would involve the construction of a dichotomous outsider variable based on a respondent's employment status at the time of a given survey (e.g. Rueda, 2007). While this approach is valuable in many instances, it has been criticized for failing to capture the non-dichotomous nature of labour market precarity and for ignoring the fluidity of modern labour markets (e.g. Jessoula et al., 2010; Schwander and Häusermann, 2013). Although this variability would ideally be captured via survey panels, most available survey data is cross-sectional. We therefore employ Schwander and Häusermann's (2013) continuous measure of labour market risk, which is based on an intersection of occupational and demographic characteristics.

In brief, this measure of "outsiderness" seeks to assess the likelihood that an individual with a given occupational and demographic profile will experience unemployment or atypical employment (regardless of their current employment status). Doing so allows us to investigate the long-term effects of exposure to labour market vulnerability, while at the same time controlling for momentary contract type. This approach has been used to investigate a variety of outcomes including social policy preferences, vote choice, and generalized trust (Häusermann et al., 2016; Rovny and Rovny, 2017; Kevins, 2018).

As per Schwander and Häusermann (2013), outsiderness scores are constructed using the following process. First, survey respondents are parsed into subgroups based on occupation, 
gender, and age (separating those over 40 from those 40 and under). The occupational categories are constructed using ISCO codes, building on previous work by Kitschelt and Rehm (2005) and Oesch (2006). Gender and age, in turn, are selected as relevant markers for labour market profiles on the basis of past research suggesting that these are key "sociostructural" determinants of labour market vulnerability in Europe (see Emmenegger et al., 2012; Schwander and Häusermann, 2013; Häusermann et al., 2016). (Note, however, that we confirm that our findings are robust to various changes to these parsing parameters (see footnote 5).)

Next, each respondent is assigned an individual "degree of outsiderness", calculated using EU-SILC micro data (Eurostat, 2018). These scores are constructed by: (1) calculating the mean subgroup rates of temporary contracts, involuntary part-time status, and unemployment; (2) subtracting these values from the corresponding country means; and (3) averaging the three (standardized deviation) scores (for further details, see Schwander and Häusermann, 2013). The result is a continuous outsiderness score, assigned to ESS respondents on the basis of their occupational and demographic profile, rather than their momentary contract status. By way of an illustration, this means that (for the 2008 survey wave) a 30-year-old female blue-collar worker in Italy would receive an outsiderness score of 1.36, while a 50-year-old male with the same occupational profile would be given a score of -0.27 - regardless of their respective (un)employment statuses on the labour market when they responded to the survey. The intuition here is that long-term exposure to labour market vulnerability should, for many attitudinal outcomes, matter independently of one's current employment status. As Rovny and Rovny (2017) lay out in a comparison of different measures of labour market precarity, looking beyond specific individual-level characteristics (e.g. contract-type, occupation, age, gender) by taking into account their intersecting influence has a key advantage: it permits us 
to incorporate into our analysis one's general experience of vulnerability and the impact of "double burdens" associated with multiple axes of labour market disadvantage.

Figure 1: Attitudes toward immigrants, by group

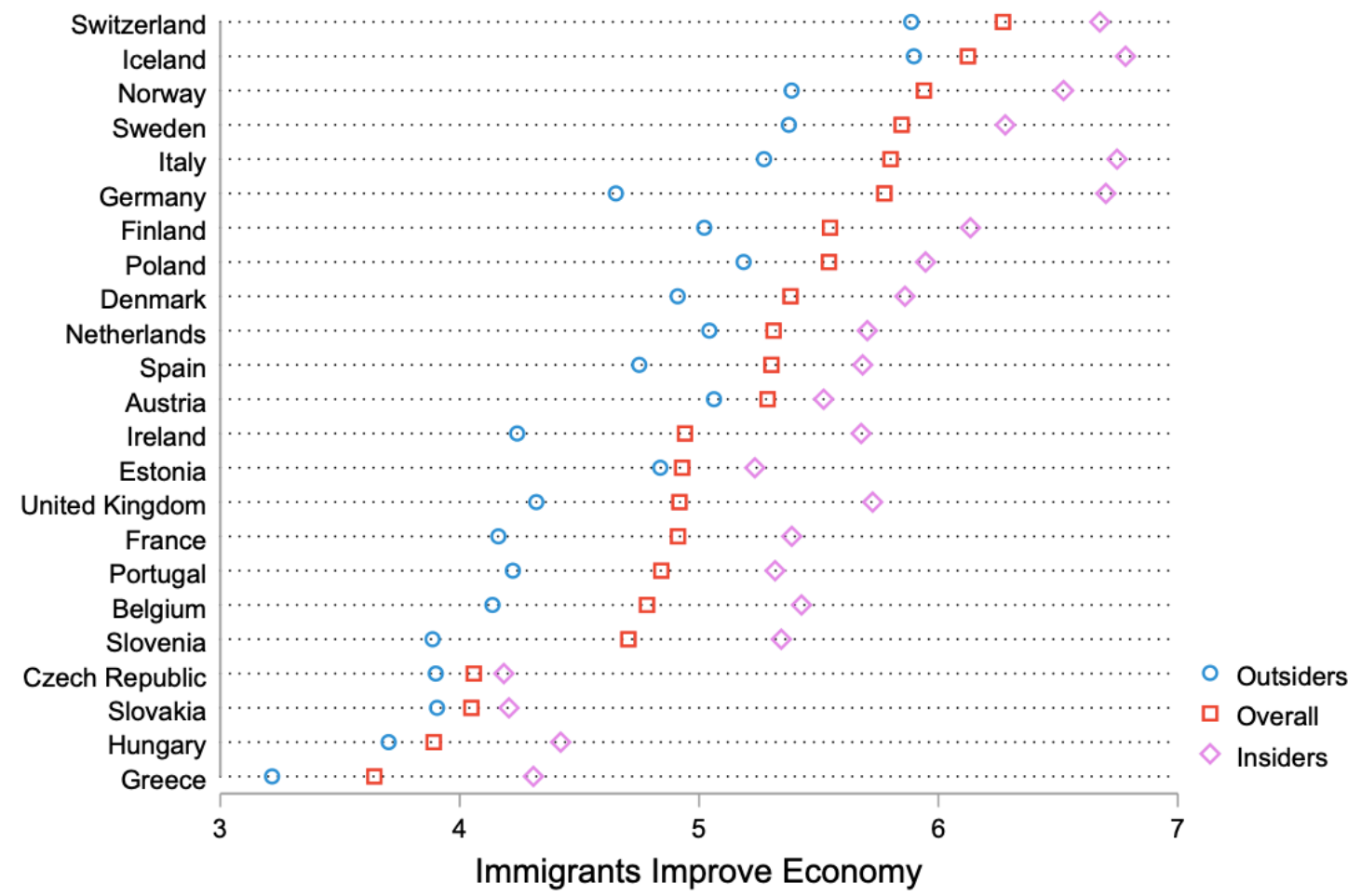

Figure $1^{\text {ii }}$ shows the weighted distribution of attitudes toward the impact of immigrants on the economy, illustrating the country means of insiders, outsiders, and overall. For ease of visualization, we treat insiders and outsiders as dichotomous categories in this instance, grouping together respondents who are one standard deviation above (outsiders) and below (insiders) the mean "outsiderness" score in a given country. Countries are listed in descending order based on their mean responses. On the whole, the figure provides initial indication that outsiders may indeed have more of a negative perception of immigrants' economic contribution than insiders, as outsiders have notably more negative responses in almost every country examined. This provides some prima facie bivariate evidence in support of $\mathrm{H} 1$. 
Controls are selected on the basis of the pre-existing literature examining factors that affect attitudes towards immigration (Paas and Halapuu, 2012; Facchini and Mayda, 2012;

Hainmueller et al., 2015). Here we pay particular attention to variables associated with labour market precarity (i.e. education, union membership, employment status, and income). At the individual level, the list of controls includes the following: education level (using the fivecategory harmonized ISCED-97 scheme); household income decile; household size, which may change the meaning of household income; gender (with males coded as 1); age and its square, to incorporate a potentially curvilinear effect; trade-union membership, given its potential influence on labour market vulnerability; labour market status controls (unemployment, part-time employment, self-employment; non-employment (i.e. those outside of the labour market)); (self-described) status as a minority; a binary variable capturing residency in a city or its suburbs (as the best available proxy in the ESS for exposure to population diversity); marital status; religion; ideology; and a binary variable for survey wave.

In addition to our two key national-level variables - the national unemployment rate and GDP (purchasing power parity) per capita, in US dollars - we also include several controls to reflect conventions in existing literature. While constructing hierarchical models with a relatively limited number of countries restricts the number of controls we can include, we incorporate key measures related to both economic performance and migrant stock, namely: year-over-year changes in GDP (purchasing power parity) per capita, in US dollars; the percentage of the population born abroad (a national-level proxy variable for exposure to population diversity); and the percentage of the migrant population (between the ages of 25 and 69) with tertiary education (to account for variation in immigrant skill level). All national-level data are taken from Eurostat, save for GDP (obtained from the OECD) and the measure of the foreign-born population (interpolated from the UN's Trends in International 
Migrant Stock: The 2015 Revision). An overview of all key variables and controls can be found in Appendix Table 2.

\section{Analysis and Discussion}

The analysis is carried out in two stages. First, we seek to establish whether outsiderness in and of itself has an impact on attitudes toward the economic contribution of immigrants. To do so, we present results from (generalized least squares) models that include only individuallevel variables and country fixed effects. ${ }^{\text {iii }}$ Next, we add country-level variables into the analysis, thereby allowing us to investigate the potential interaction between labour market precarity, GDP, and unemployment rates. This is done via a set of hierarchical models (employing maximum likelihood estimation and incorporating both design and population weights) constructed in line with current best practices: namely, the 57051 respondents are nested within 72 country-year clusters, which are themselves nested within 23 countries. As Schmidt-Catran and Fairbrother (2016) have demonstrated, by constructing the models in this manner and then adding survey wave binary variables to the regressions, the analysis returns more accurate (i.e. conservative) results.

Both sets of models are built stepwise, to ensure that the findings are not simply the result of a particular model construction. Furthermore, while the initial set of models incorporating country-level variables allow only the intercepts to vary, the final full model allows for random slopes as well. This last (random-intercepts, random-slope) model provides a stricter test of our hypotheses, permitting the possibility that unobserved country-level variation may lead outsiderness to have different attitudinal impacts in different countries.

Table 1 presents the results of the individual-level only models. Model 1 includes only the key independent variable, while the standard and extended controls are added to Models 2 
Table 1: Individual-level models

\begin{tabular}{|c|c|c|c|}
\hline & Model 1 & Model 2 & Model 3 \\
\hline Outsiderness & $\begin{array}{c}-0.492^{* * *} \\
(0.015)\end{array}$ & $\begin{array}{c}-0.216^{* * *} \\
(0.019)\end{array}$ & $\begin{array}{c}-0.221^{* * *} \\
(0.019)\end{array}$ \\
\hline \multicolumn{4}{|l|}{$\begin{array}{l}\text { Education: baseline }-< \\
\text { lower secondary }\end{array}$} \\
\hline Lower secondary & & $\begin{array}{l}0.162^{* *} \\
(0.053)\end{array}$ & $\begin{array}{l}0.166^{* *} \\
(0.052)\end{array}$ \\
\hline Upper secondary & & $\begin{array}{l}0.428^{* * *} \\
(0.050)\end{array}$ & $\begin{array}{l}0.427^{* * *} \\
(0.050)\end{array}$ \\
\hline Post-secondary non-tertiary & & $\begin{array}{c}0.632^{* * * *} \\
(0.061)\end{array}$ & $\begin{array}{l}0.615^{* * *} \\
(0.061)\end{array}$ \\
\hline Tertiary education & & $\begin{array}{l}1.295^{* * *} \\
(0.051)\end{array}$ & $\begin{array}{l}1.238^{* * *} \\
(0.051)\end{array}$ \\
\hline Income decile & & $\begin{array}{c}0.0577^{* * *} \\
(0.004)\end{array}$ & $\begin{array}{c}0.0627^{* * *} \\
(0.004)\end{array}$ \\
\hline Household size & & $\begin{array}{c}-0.0558^{* * *} \\
(0.008)\end{array}$ & $\begin{array}{c}-0.0484^{* * *} \\
(0.008)\end{array}$ \\
\hline Male & & $\begin{array}{c}0.147^{* * *} \\
(0.023)\end{array}$ & $\begin{array}{l}0.161^{* * *} \\
(0.022)\end{array}$ \\
\hline Age & & $\begin{array}{c}-0.00571 \\
(0.005)\end{array}$ & $\begin{array}{c}-0.00551 \\
(0.005)\end{array}$ \\
\hline Age \# Age & & $\begin{array}{l}0.0000424 \\
(0.000)\end{array}$ & $\begin{array}{c}0.0000404 \\
(0.000)\end{array}$ \\
\hline Trade union member & & $\begin{array}{c}0.00130 \\
(0.024)\end{array}$ & $\begin{array}{l}-0.0312 \\
(0.023)\end{array}$ \\
\hline Unemployed & & $\begin{array}{c}-0.157^{* * * *} \\
(0.036)\end{array}$ & $\begin{array}{c}-0.197^{* * *} \\
(0.036)\end{array}$ \\
\hline Self employed & & $\begin{array}{c}-0.00167 \\
(0.030)\end{array}$ & $\begin{array}{l}0.0394 \\
(0.030)\end{array}$ \\
\hline Part-time employed & & $\begin{array}{c}0.0881^{* * *} \\
(0.025)\end{array}$ & $\begin{array}{l}0.0703^{* *} \\
(0.025)\end{array}$ \\
\hline Non-employed & & $\begin{array}{l}0.255^{* * *} \\
(0.025)\end{array}$ & $\begin{array}{l}0.238^{* * *} \\
(0.024)\end{array}$ \\
\hline Self-identified minority & & $\begin{array}{c}0.631^{* * *} \\
(0.043)\end{array}$ & $\begin{array}{l}0.412^{* * *} \\
(0.045)\end{array}$ \\
\hline City resident & & & $\begin{array}{l}0.300^{* * *} \\
(0.020)\end{array}$ \\
\hline Married & & & $\begin{array}{l}0.0436^{*} \\
(0.022)\end{array}$ \\
\hline Religion: baseline - none & & & \\
\hline Catholic & & & $\begin{array}{c}-0.0614^{*} \\
(0.026)\end{array}$ \\
\hline Protestant & & & $\begin{array}{l}0.0198 \\
(0.028)\end{array}$ \\
\hline Other & & & $\begin{array}{l}0.370^{* * *} \\
(0.045)\end{array}$ \\
\hline Ideology & & & $\begin{array}{c}-0.103^{* * *} \\
(0.004)\end{array}$ \\
\hline Survey wave: Baseline - 2008 & & & \\
\hline 2010 & $\begin{array}{c}-0.178^{* * *} \\
(0.027)\end{array}$ & $\begin{array}{c}-0.141^{* * *} \\
(0.026)\end{array}$ & $\begin{array}{c}-0.134^{* * *} \\
(0.026)\end{array}$ \\
\hline 2012 & $\begin{array}{r}-0.0734^{*} \\
(0.029)\end{array}$ & $\begin{array}{r}-0.0488^{+} \\
(0.028)\end{array}$ & $\begin{array}{c}-0.0479^{+} \\
(0.028)\end{array}$ \\
\hline 2014 & $\begin{array}{c}-0.186^{* * *} \\
(0.027)\end{array}$ & $\begin{array}{c}-0.196^{* * *} \\
(0.027)\end{array}$ & $\begin{array}{c}-0.199^{* * *} \\
(0.027)\end{array}$ \\
\hline Constant & $\begin{array}{l}5.263^{* * *} \\
(0.020)\end{array}$ & $\begin{array}{c}4.363^{* * *} \\
(0.109)\end{array}$ & $\begin{array}{l}4.740^{* * *} \\
(0.113)\end{array}$ \\
\hline
\end{tabular}


Note: Cells contain generalized least squares fixed-effects regression coefficients, with standard errors in parentheses.

${ }^{+} p<0.10,{ }^{*} p<0.05,{ }^{* *} p<0.01,{ }^{* * *} p<0.001$

and 3 respectively. Outsiderness is statistically significant in each instance, with an effect size of approximately -0.22 . Moving from one standard deviation below to one standard deviation above the mean level of outsiderness would thus be correlated, on average, with an impact of just over -0.3 . This gives the variable an effect size comparable to or larger than numerous standard controls (e.g. unemployment, income, city residence), even holding constant many factors that are closely related to labour market vulnerability. Indeed, only education and minority status have substantially larger effects. We thus find confirmation for Hypothesis 1: increased outsiderness is associated with more negative attitudes regarding the economic contribution of immigrants.

Table 2 then presents the full models, with national-level controls added in order to test Hypotheses 2, 3, and 4. The cross-level interaction between outsiderness and GDP and the unemployment rate is central, so the key regression results should be read carefully: specifically, the coefficients for outsiderness and the two national-level measures on their own display the effect where the other variable is set to zero, while the interaction coefficient indicates the result of changing either variable by one unit while holding the other constant. Overall, the significance levels of the interaction effects suggest that the unemployment rate does not appear to have an effect on the impact of outsiderness - thus failing to support Hypothesis 2 - but that GDP does. While outsiderness (unsurprisingly) has no effect where GDP is set to 0 (as evidenced by the lack of statistical significance for the direct effect in the model) $)^{\text {iv }}$, as GDP levels increase, so too does the gap between insider and outsider attitudes toward the economic contribution of immigrants. We thus find support for Hypothesis 3 rather than Hypothesis 4: outsiderness has a larger negative effect on attitudes towards the 
Table 2: Models with country-level variables

\begin{tabular}{|c|c|c|c|c|}
\hline & Model 1 & Model 2 & Model 3 & Model 4 \\
\hline Outsiderness & $\begin{array}{l}-0.409^{*} \\
(0.185)\end{array}$ & $\begin{array}{c}0.171 \\
(0.139)\end{array}$ & $\begin{array}{c}0.174 \\
(0.137)\end{array}$ & $\begin{array}{c}0.181 \\
(0.114)\end{array}$ \\
\hline \multicolumn{5}{|l|}{$\begin{array}{l}\text { Education: baseline }-<\text { lower } \\
\text { secondary }\end{array}$} \\
\hline Lower secondary & & $\begin{array}{l}0.0944 \\
(0.089)\end{array}$ & $\begin{array}{l}0.0944 \\
(0.089)\end{array}$ & $\begin{array}{l}0.0926 \\
(0.088)\end{array}$ \\
\hline Upper secondary & & $\begin{array}{l}0.331^{* * * *} \\
(0.077)\end{array}$ & $\begin{array}{l}0.331^{* * * *} \\
(0.077)\end{array}$ & $\begin{array}{l}0.331^{* * * *} \\
(0.075)\end{array}$ \\
\hline Post-secondary non-tertiary & & $\begin{array}{l}0.571^{* * *} \\
(0.083)\end{array}$ & $\begin{array}{l}0.570^{* * *} \\
(0.084)\end{array}$ & $\begin{array}{l}0.573^{* * *} \\
(0.086)\end{array}$ \\
\hline Tertiary education & & $\begin{array}{l}1.166^{* * *} \\
(0.048)\end{array}$ & $\begin{array}{l}1.166^{* * *} \\
(0.048)\end{array}$ & $\begin{array}{l}1.161^{* * *} \\
(0.049)\end{array}$ \\
\hline Income decile & & $\begin{array}{l}0.0764^{* * *} \\
(0.007)\end{array}$ & $\begin{array}{c}0.0765^{* * *} \\
(0.007)\end{array}$ & $\begin{array}{c}0.0753^{* * *} \\
(0.008)\end{array}$ \\
\hline Household size & & $\begin{array}{c}-0.0609^{* * *} \\
(0.012)\end{array}$ & $\begin{array}{c}-0.0609^{* * *} \\
(0.012)\end{array}$ & $\begin{array}{c}-0.0605^{* * *} \\
(0.012)\end{array}$ \\
\hline Male & & $\begin{array}{l}0.228^{* *} \\
(0.083)\end{array}$ & $\begin{array}{l}0.228^{* *} \\
(0.083)\end{array}$ & $\begin{array}{l}0.221^{* *} \\
(0.083)\end{array}$ \\
\hline Age & & $\begin{array}{c}0.00331 \\
(0.013)\end{array}$ & $\begin{array}{c}0.00332 \\
(0.013)\end{array}$ & $\begin{array}{c}0.00322 \\
(0.012)\end{array}$ \\
\hline Age \# Age & & $\begin{array}{c}-0.00006 \\
(0.000)\end{array}$ & $\begin{array}{c}-0.00006 \\
(0.000)\end{array}$ & $\begin{array}{c}-0.00006 \\
(0.000)\end{array}$ \\
\hline Trade union member & & $\begin{array}{l}0.0126 \\
(0.055)\end{array}$ & $\begin{array}{l}0.0133 \\
(0.055)\end{array}$ & $\begin{array}{l}0.0142 \\
(0.053)\end{array}$ \\
\hline Unemployed & & $\begin{array}{l}-0.115^{*} \\
(0.056)\end{array}$ & $\begin{array}{l}-0.115^{*} \\
(0.056)\end{array}$ & $\begin{array}{l}-0.114^{*} \\
(0.056)\end{array}$ \\
\hline Self employed & & $\begin{array}{l}0.0645 \\
(0.040)\end{array}$ & $\begin{array}{l}0.0647 \\
(0.040)\end{array}$ & $\begin{array}{l}0.0620 \\
(0.039)\end{array}$ \\
\hline Part-time employed & & $\begin{array}{l}0.121^{* * *} \\
(0.032)\end{array}$ & $\begin{array}{l}0.120^{* * *} \\
(0.032)\end{array}$ & $\begin{array}{l}0.127^{* * *} \\
(0.030)\end{array}$ \\
\hline Non-employed & & $\begin{array}{l}0.266^{* * *} \\
(0.058)\end{array}$ & $\begin{array}{l}0.266^{* * *} \\
(0.058)\end{array}$ & $\begin{array}{l}0.263^{* * *} \\
(0.059)\end{array}$ \\
\hline Self-identified minority & & $\begin{array}{l}0.464^{* *} \\
(0.143)\end{array}$ & $\begin{array}{l}0.464^{* *} \\
(0.143)\end{array}$ & $\begin{array}{l}0.462^{* *} \\
(0.142)\end{array}$ \\
\hline City resident & & $\begin{array}{l}0.305^{* * *} \\
(0.033)\end{array}$ & $\begin{array}{l}0.305^{* * *} \\
(0.033)\end{array}$ & $\begin{array}{l}0.306^{* * * *} \\
(0.033)\end{array}$ \\
\hline Married & & $\begin{array}{c}0.00739 \\
(0.027)\end{array}$ & $\begin{array}{c}0.00743 \\
(0.027)\end{array}$ & $\begin{array}{c}0.00802 \\
(0.027)\end{array}$ \\
\hline Religion: baseline - none & & & & \\
\hline Catholic & & $\begin{array}{l}-0.0507 \\
(0.100)\end{array}$ & $\begin{array}{l}-0.0508 \\
(0.100)\end{array}$ & $\begin{array}{l}-0.0540 \\
(0.101)\end{array}$ \\
\hline Protestant & & $\begin{array}{c}-0.00320 \\
(0.105)\end{array}$ & $\begin{array}{c}-0.00307 \\
(0.105)\end{array}$ & $\begin{array}{c}-0.00465 \\
(0.105)\end{array}$ \\
\hline Other & & $\begin{array}{c}0.506^{* * *} \\
(0.109)\end{array}$ & $\begin{array}{c}0.505^{* * *} \\
(0.109)\end{array}$ & $\begin{array}{c}0.502^{* * *} \\
(0.110)\end{array}$ \\
\hline Ideology & & $\begin{array}{c}-0.140^{* * *} \\
(0.035)\end{array}$ & $\begin{array}{c}-0.140^{* * *} \\
(0.035)\end{array}$ & $\begin{array}{c}-0.139^{* * *} \\
(0.035)\end{array}$ \\
\hline GDP per capita & $\begin{array}{c}0.0000359^{* *} \\
\quad(0.000)\end{array}$ & $\begin{array}{c}0.0000291^{*} \\
(0.000)\end{array}$ & $\begin{array}{c}0.0000179 \\
(0.000)\end{array}$ & $\begin{array}{c}0.0000183 \\
(0.000)\end{array}$ \\
\hline Outsiderness \# GDP per capita & $\begin{array}{c}-0.000005 \\
(0.000)\end{array}$ & $\begin{array}{c}-0.00001^{* *} \\
(0.000)\end{array}$ & $\begin{array}{c}-0.00001^{* *} \\
(0.000)\end{array}$ & $\begin{array}{c}-0.000009^{* * *} \\
\quad(0.000)\end{array}$ \\
\hline Unemployment rate & $\begin{array}{l}-0.0171 \\
(0.019)\end{array}$ & $\begin{array}{l}-0.0162 \\
(0.016)\end{array}$ & $\begin{array}{l}-0.0256 \\
(0.017)\end{array}$ & $\begin{array}{l}-0.0255 \\
(0.017)\end{array}$ \\
\hline $\begin{array}{l}\text { Outsiderness \# Unemployment } \\
\text { rate } \\
\text { Survey Wave: Baseline - } 2008\end{array}$ & $\begin{array}{c}0.00669 \\
(0.006)\end{array}$ & $\begin{array}{c}0.000650 \\
(0.005)\end{array}$ & $\begin{array}{c}0.000594 \\
(0.005)\end{array}$ & $\begin{array}{c}-0.00316 \\
(0.004)\end{array}$ \\
\hline
\end{tabular}




\begin{tabular}{|c|c|c|c|c|}
\hline 2010 & $\begin{array}{l}-0.0753 \\
(0.100)\end{array}$ & $\begin{array}{r}-0.0515 \\
(0.105)\end{array}$ & $\begin{array}{l}-0.0107 \\
(0.093)\end{array}$ & $\begin{array}{l}-0.0127 \\
(0.093)\end{array}$ \\
\hline 2012 & -0.126 & -0.0965 & 0.0172 & 0.0216 \\
\hline 2014 & $\begin{array}{l}(0.092) \\
-0.312^{*} \\
(0.122)\end{array}$ & $\begin{array}{l}(0.096) \\
-0.303^{*} \\
(0.124)\end{array}$ & $\begin{array}{l}(0.107) \\
-0.164 \\
(0.142)\end{array}$ & $\begin{array}{l}(0.108) \\
-0.167 \\
(0.141)\end{array}$ \\
\hline Change in GDP per capita & & & $\begin{array}{c}0.0000509^{*} \\
(0.000)\end{array}$ & $\begin{array}{c}0.0000511^{+} \\
(0.000)\end{array}$ \\
\hline Migrant stock (\% of pop.) & & & $\begin{array}{l}0.0297^{+} \\
(0.018)\end{array}$ & $\begin{array}{l}0.0292^{+} \\
(0.018)\end{array}$ \\
\hline $\begin{array}{l}\text { Skilled migrants ( } \% \text { of } \\
\text { migrants) }\end{array}$ & & & $\begin{array}{c}-0.00946 \\
(0.009)\end{array}$ & $\begin{array}{c}-0.00970 \\
(0.009)\end{array}$ \\
\hline Constant & $\begin{array}{l}3.959^{* * *} \\
(0.564)\end{array}$ & $\begin{array}{l}3.711^{* * *} \\
(0.513)\end{array}$ & $\begin{array}{l}4.030^{* * *} \\
(0.589) \\
\end{array}$ & $\begin{array}{l}4.043^{* * *} \\
(0.581) \\
\end{array}$ \\
\hline $\begin{array}{l}\text { Variances } \\
\text { Country }\end{array}$ & $\begin{array}{l}0.506^{* * *} \\
(0.087)\end{array}$ & $\begin{array}{l}0.586^{*} \\
(0.122)\end{array}$ & $\begin{array}{l}0.600^{*} \\
(0.151)\end{array}$ & $\begin{array}{l}0.0961^{* * *} \\
(0.021)\end{array}$ \\
\hline Country-year & $\begin{array}{l}0.190^{* * *} \\
(0.027)\end{array}$ & $\begin{array}{l}0.171^{* * *} \\
(0.022)\end{array}$ & $\begin{array}{l}0.157^{* * *} \\
(0.020)\end{array}$ & $\begin{array}{l}0.0747^{* * *} \\
(0.017)\end{array}$ \\
\hline Residual & $\begin{array}{l}2.274^{* * *} \\
(0.034) \\
\end{array}$ & $\begin{array}{l}2.177^{* * *} \\
(0.031)\end{array}$ & $\begin{array}{l}2.177^{* * *} \\
(0.031) \\
\end{array}$ & $\begin{array}{l}2.175^{* * *} \\
(0.031)\end{array}$ \\
\hline $\begin{array}{l}\text { Level-3 } \\
\text { variance (Outsiderness) }\end{array}$ & & & & $\begin{array}{l}0.157^{* * *} \\
(0.020)\end{array}$ \\
\hline $\begin{array}{l}\text { Level-2 } \\
\text { variance (Outsiderness) }\end{array}$ & & & & $\begin{array}{l}0.600^{*} \\
(0.150)\end{array}$ \\
\hline Observations & 57051 & 57051 & 57051 & 57051 \\
\hline Country-years & 72 & 72 & 72 & 72 \\
\hline Countries & 23 & 23 & 23 & 23 \\
\hline
\end{tabular}

Note: Cells contain maximum likelihood regression coefficients, with standard errors in parentheses. All models incorporate survey weights.

${ }^{+} p<0.10,{ }^{*} p<0.05,{ }^{* *} p<0.01,{ }^{* * *} p<0.001$

economic contribution of immigrants in stronger economies (i.e. those with higher GDP per capita).

Given the difficulty of reading such a model by regression output alone, Figure 2 illustrates this relationship via a marginal effects plot, including 95 percent confidence intervals and a density plot of respondent distribution (illustrated in the background via a dashed line). Here we plot the results from the (more conservative) model with random slopes (Model 4), though effect sizes are only modestly smaller than with the random-intercepts only model (Model 3). Extreme values of GDP in the sample (both the top and bottom 5 percent) are 
Figure 2: Marginal effects of outsiderness by GDP (PPP) per capita (based on Model 4), with density plot of respondent distribution

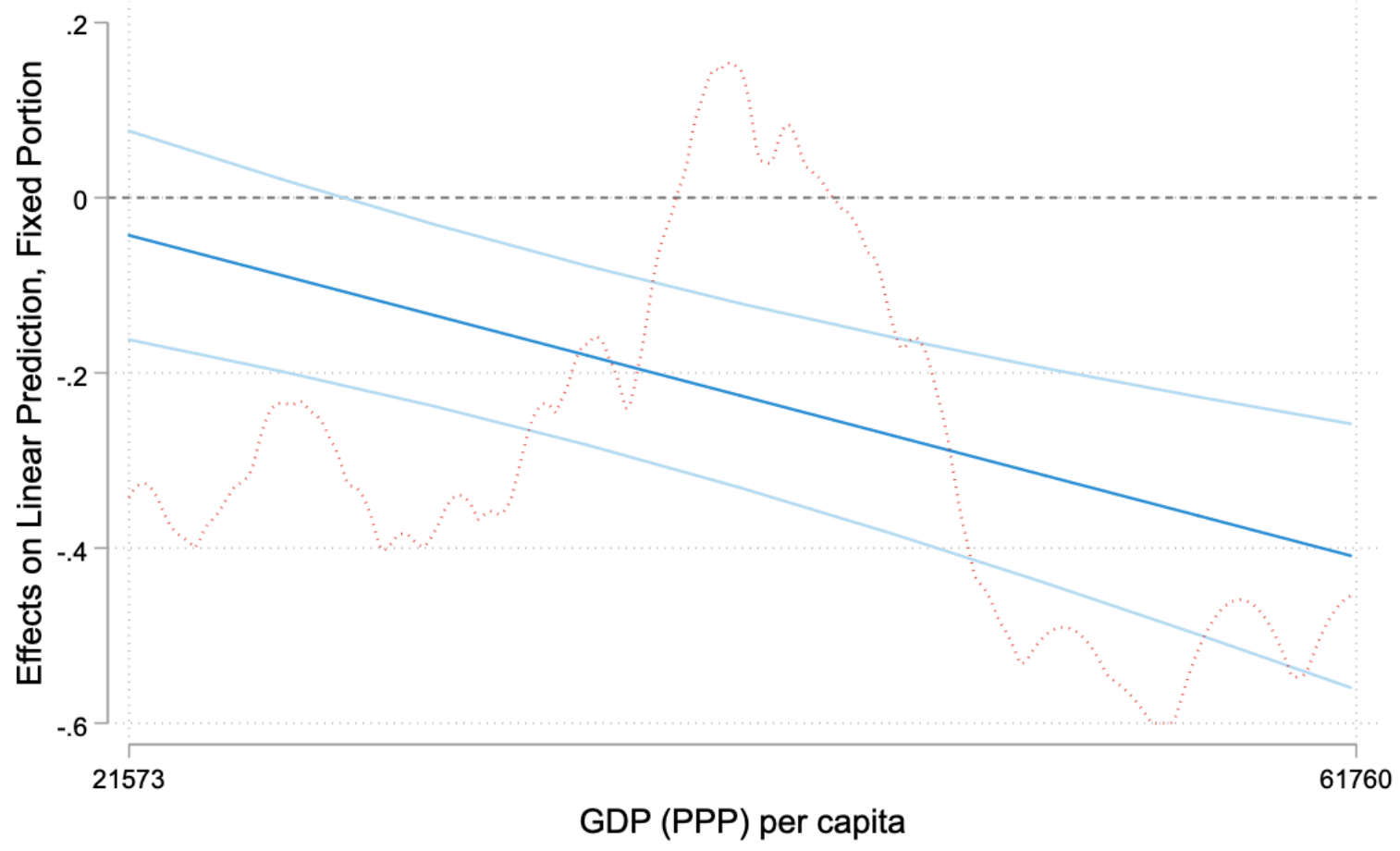

excluded from the figures to provide a clearer picture of typical effects. Results show that the effect of outsiderness on attitudes toward the economic contribution of immigrants is not statistically distinguishable from zero where GDP is at the lower end of the spectrum, but that the effect increases substantially as GDP increases, eventually reaching -0.4 .

Figure 3 presents an alternative visualization of the same findings. Here we plot the predictive margins (across the truncated range of GDP values) for an insider at the $10^{\text {th }}$ percentile of outsiderness, an outsider at the $90^{\text {th }}$ percentile, and an "average" worker at the mean. By doing so, we are able to assess how three hypothetical respondents would perceive the economic contribution of immigrants at different levels of GDP. Holding all other variables at their means, the figure illustrates a growing gap between the responses of insiders and outsiders as the level of GDP per capita increases: while the predicted margins for both the insider and outsider are similar at low levels of GDP (with responses hovering around 


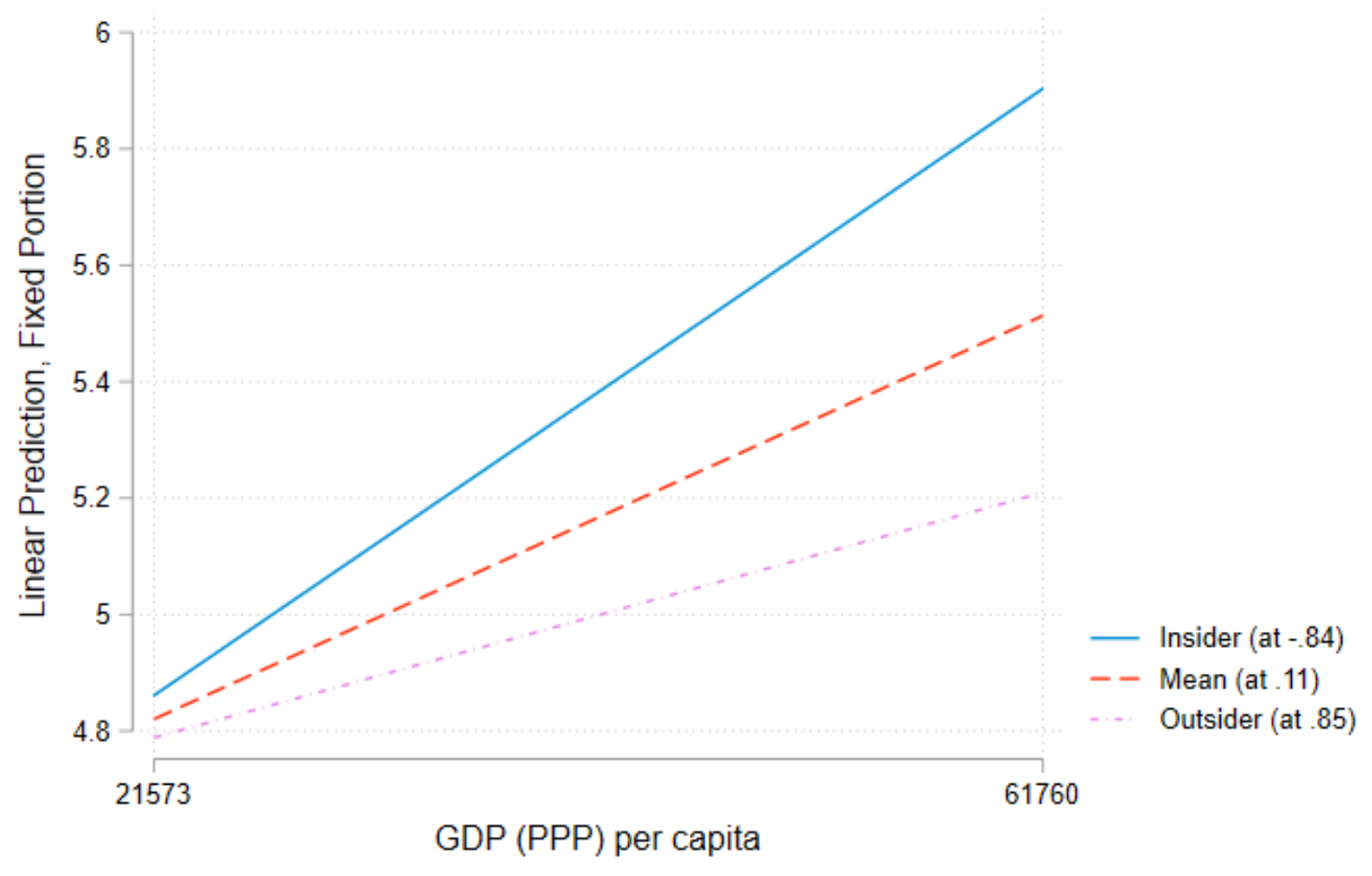

4.8), at high levels they differ by about 0.7 (with responses at approximately 5.9 and 5.2 respectively). We thus find that, although attitudes toward the economic contribution of immigrants are generally more negative in lower GDP countries, labour market vulnerability contributes to opinion polarization on the issue in wealthier countries; this potential for attitude polarization is especially clear when we recall that outsiders are more likely than insiders to have lower income levels (as well as, in some instances, lower education levels) and to experience stints of unemployment- all factors which our models suggest compound anti-immigrant sentiment.

Finally, we conduct a series of robustness checks to confirm our key findings. In addition to testing the effects of various changes to our standard regression models, ${ }^{\mathrm{v}}$ these analyses include: re-running both the individual-level only and full models 23 times each, dropping one country at a time to ensure that the results are not driven by any particular country (i.e. 
remove-one jackknife); incorporating cluster robust standard errors into the full-model; and re-conducting the main analysis without survey weights (see Appendix Table 3 for full results). This analysis confirms that (1) the effect of labour market vulnerability is robust to the aforementioned checks and (2) the interaction between labour market vulnerability and GDP per capita remains consistent, save for in the case of remove-one jackknifing $(p=0.10)$; given the limited number of cases and the comparatively high number of controls, however, we do not consider this to be a striking limitation.

\section{Conclusion}

The results of our investigation suggest that: (1) outsiderness is correlated with more negative beliefs about the economic contribution of immigrants, even when we control for related factors such as education and contract type; and (2) the size of outsiderness' effect is moderated by GDP per capita, with insiders and outsiders holding more distinct attitudes in higher GDP countries. Unemployment rates, by contrast, do not appear to shape the effect of labour market vulnerability on attitudes toward the economic impact of immigrants. Overall, these findings address limitations in the existing literature, most notably, the prior lack of knowledge about the impact of respondents' positions on the labour market, as opposed to their education and/or skill level, on perceptions of the economic contribution of immigrants. At the national level, we address the dispute as to whether it is affluence or unemployment that most affects attitudes, finding that it is broad resource availability in the economy, rather than on the labour market, that seems to be crucial.

Our study takes on added import in Europe and beyond given the ongoing decline of the Standard Employment Relationship based on full-time, permanent work with a single employer, both as a reality and a normative ideal (Vosko, 2009; Kalleberg, 2009; Lightman 
and Good Gingrich, 2018). Thus, there are strong reasons to believe that rates of labour market precarity will continue to increase into the future. The demonstrated association between outsiderness and negative perceptions of the economic contribution of immigrants is especially worrisome given research suggesting that such fears are tied to broader antiimmigrant attitudes and support for populist and radical right-wing parties (Hainmueller et al., 2015; Kehrberg, 2015).

We conclude by highlighting several areas for future research to build on our findings. First, our study was only able to incorporate proxy variables to assess individual contact with immigrants; given that research emphasizes the importance of contact with minorities as a means to foster out-group trust and solidarity (Putnam, 2007; Allport, 1954), studies that include a more direct measure would offer a considerable advancement. Second, we note that our study does not address the specific perceptions of immigrants themselves. Thus, datasets with appropriate sample sizes of immigrant populations could allow for discrete analyses of the impact of outsiderness on immigrants' own sentiments. Third, and finally, future research drawing out the relationship between outsiderness and different facets of anti-immigrant sentiment would be particularly welcome, especially in light of the relatively high correlation between the standard survey items available in the ESS. While this would be a difficult task solely on the basis of pre-existing survey data, careful survey experimentation could be a valuable route toward disentangling the myriad components of attitudes towards immigration.

\footnotetext{
${ }^{\mathrm{i}}$ While the 2012 and 2014 waves employed the ISCO-08 coding in lieu of ISCO-88, we convert the categorizations to align across waves. This results in a modest loss of data: namely, we lose six occupational classifications (out of 670 ), which together amount to $0.3 \%$ of respondents in the two affected waves.

ii All figures are drawn using “plotplain” (Bischof, 2017).

iii Although survey weights cannot be included in this model for technical reasons, we ran an alternative model (using country binary variables) to confirm that weighting has no substantial impact on the main findings.
} 
${ }^{\text {iv }}$ Note that this does not mean that outsiderness does not affect attitudes toward immigrants in these models. Centring the GDP variable, for instance, results in a statistically significant coefficient.

${ }^{v}$ Namely, we confirmed: that our findings are not dependent on our specific construction of the outsiderness scores (i.e. changing the age cut-offs to 35 or 30 , adding a foreign/native-born division); that countries with particularly low sample sizes (i.e. Italy and Iceland) are not driving our key findings; that the results remain even if we exclude the 2014 survey wave, for which the EU-SILC ISCO data (used to construct outsiderness scores) are not entirely backwards compatible; and that the findings are robust to including a post-communist dichotomous variable. Finally, we also re-ran all of our analysis with general attitudes toward immigration as the dependent variable (using an IRT index based on the economic, cultural, and overall impact of immigration). Results suggest a similar relationship, though the (proportionally adjusted) size of the effect is notably smaller arguably due to the additional (non-economy related) noise introduced by the additional survey items. 


\section{Works Cited:}

Allport GW. (1954) The Nature of Prejudice, New York: Addison-Wesley Publishing Company.

Anderson CJ. (2009) The private consequences of public policies: active labor market policies and social ties in Europe. European Political Science Review 1: 341-373.

Berger S and Piore MJ. (1980) Dualism and Discontinuity in Industrial Societies, New York, NY: Cambridge University Press.

Bergh J. (2006) Gender attitudes and modernization processes. International Journal of Public Opinion Research 19: 5-23.

Bischof D. (2017) New Figure Schemes for Stata: plotplain \&plottig. The Stata Journal 17: 748-759.

Borjas GJ. (2003) The labor demand curve is downward sloping: Reexamining the impact of immigration on the labor market. The quarterly journal of economics 118: 1335-1374.

Borjas GJ. (2006) Native internal migration and the labor market impact of immigration. Journal of Human resources 41: 221-258.

Burns P and Gimpel JG. (2000) Economic insecurity, prejudicial stereotypes, and public opinion on immigration policy. Political science quarterly 115: 201-225.

Card D. (2001) Immigrant inflows, native outflows, and the local labor market impacts of higher immigration. Journal of Labor Economics 19: 22-64.

Card D, Dustmann C and Preston I. (2012) Immigration, wages, and compositional amenities. Journal of the European Economic Association 10: 78-119.

Chang HI and Kang WC. (2015) Trust, Economic Development and Attitudes Toward Immigration. (Under review).

Cochrane C and Nevitte N. (2014) Scapegoating: Unemployment, far-right parties and antiimmigrant sentiment. Comparative European Politics 12: 1-32. 
Cranford CJ and Vosko LF. (2006) Conceptualizing precarious employment: Mapping wage work across social location and occupational context. In: Vosko LF (ed) Precarious employment: Understanding labour market insecurity in Canada. Montreal, QC: McGill-Queen's Unvirsity Press, 43-66.

Cutts D, Ford R and Goodwin MJ. (2011) Anti-immigrant, politically disaffected or still racist after all? Examining the attitudinal drivers of extreme right support in Britain in the 2009 European elections. European Journal of Political Research 50: 418-440.

D'Addio AC and Rosholm M. (2005) Temporary Employment in Europe: Characteristics, Determinants and Outcomes. Brussels Economic Review 48: 13-41.

Dancygier RM and Donnelly MJ. (2012) Sectoral economies, economic contexts, and attitudes toward immigration. The journal of politics 75: 17-35.

Donnelly MJ. (2016) Competition and solidarity: union members and immigration in Europe. West European Politics 39: 688-709.

Dustmann C, Fabbri F and Preston I. (2005) The impact of immigration on the British labour market. The Economic Journal 115.

Emmenegger P, Haüsermann S, Palier B, et al. (2012) The Age of Dualization, Oxford, UK: Oxford University Press.

ESS. (2008) European Social Survey Round 4 Data.

ESS. (2010) European Social Survey Round 5 Data.

ESS. (2012) European Social Survey Round 6 Data.

ESS. (2014) European Social Survey Round 7 Data.

Eurostat. (2018) Income and Living Conditions Dataset. In: Eurostat (ed). Luxembourg. Facchini G and Mayda AM. (2012) Individual attitudes towards skilled migration: An empirical analysis across countries. The World Economy 35: 183-196. 
Finseraas H. (2009) Income Inequality and Demand for Redistribution: A Multilevel Analysis of European Public Opinion. Scandinavian Political Studies 32: 94-119.

Gash V and McGinnity F. (2007) Fixed-term contracts — the new European inequality? Comparing men and women in West Germany and France. Socio-Economic Review 5: 467-496.

Gaston N and Nelson D. (2000) Immigration and labour-market outcomes in the United States: a political-economy puzzle. Oxford Review of Economic Policy 16: 104-114.

Goldring L and Landolt P. (2012) The Impact of Precarious Legal Status on Immigrants' Economic Outcomes. IRPP Study: 1.

Goldring L and Landolt P. (2014) Transnational Migration and the Reformulation of Analytical Categories: Unpacking Latin American Refugee Dynamics in Toronto. The Practice of Research on Migration and Mobilities. Springer, 103-127.

Hainmueller J and Hiscox MJ. (2007) Educated preferences: Explaining attitudes toward immigration in Europe. International organization 61: 399-442.

Hainmueller J, Hiscox MJ and Margalit Y. (2015) Do concerns about labor market competition shape attitudes toward immigration? New evidence. Journal of International Economics 97: 193-207.

Hainmueller J and Hopkins DJ. (2014) Public attitudes toward immigration. Annual Review of Political Science 17: 225-249.

Häusermann S, Kurer T and Schwander H. (2014) High-skilled outsiders? Labor market vulnerability, education and welfare state preferences. Socio-Economic Review 13: $235-258$.

Häusermann S, Kurer T and Schwander H. (2016) Sharing the Risk? Households, Labor Market Vulnerability, and Social Policy Preferences in Western Europe. The journal of politics 78: 1045-1060. 
Haüsermann S and Schwander H. (2012) Varieties of Dualization? Labor Market

Segmentation and Insider-Outsider Divides Across Regimes. In: Emmenegger P, Haüsermann S, Palier B, et al. (eds) The Age of Dualization: The Changing Face of Inequality in Deindustrializing Societies. Oxford, UK: Oxford University Press, 2751.

Jackman RW and Volpert K. (1996) Conditions Favouring Parties of the Extreme Right in Western Europe. British Journal of Political Science 26: 501-521.

Jessoula M, Graziano P and Madama I. (2010) 'Selective Flexicurity' in Segmented Labor Markets: The Case of Italian 'Mid-Siders'. Journal of Social Policy 39: 561-583.

Kalleberg AL. (2009) Precarious work, insecure workers: Employment relations in transition. American Sociological Review 74: 1-22.

Kaya Y and Karakoç E. (2012) Civilizing vs destructive globalization? A multi-level analysis of anti-immigrant prejudice. International Journal of Comparative Sociology 53: 2344.

Kehrberg JE. (2007) Public opinion on immigration in Western Europe: Economics, tolerance, and exposure. Comparative European Politics 5: 264-281.

Kehrberg JE. (2015) The demand side of support for radical right parties. Comparative European Politics 13: 553-576.

Kevins A. (2015) Political Actors, Public Opinion, and the Extension of Welfare Coverage. Journal of European Social Policy 25: 303-315.

Kevins A. (2017) Expanding Welfare in an Age of Austerity: Increasing Protection in an Unprotected World, Amsterdam, NL: Amsterdam University Press.

Kevins A. (2018) Dualized trust: risk, social trust and the welfare state. Socio-Economic Review. 
Kitschelt H and Rehm P. (2005) Work, Family and Politics: Foundations of Electoral Partisan Alignments in Postindustrial Democracies. Annual Meeting of the American Political Science Association.

Krings T. (2009) A race to the bottom? Trade unions, EU enlargement and the free movement of labour. European Journal of Industrial Relations 15: 49-69.

Lightman N and Gingrich LG. (2013) The Intersecting Dynamics of Social Exclusion: Age, Gender, Race and Immigrant Status in Canada's Labour Market. Canadian Ethnic Studies 44: 121-145.

Lightman N and Good Gingrich L. (2018) Measuring economic exclusion for racialized minorities, immigrants and women in Canada: results from 2000 and 2010. Journal of Poverty 22: 398-420.

Malchow-Møller N, Munch JR, Schroll S, et al. (2008) Attitudes towards immigrationPerceived consequences and economic self-interest. Economics Letters 100: 254-257. Marx P. (2014) Labour market risks and political preferences: The case of temporary employment. European Journal of Political Research 53: 136-159.

Mayda AM. (2006) Who is against immigration? A cross-country investigation of individual attitudes toward immigrants. The review of Economics and Statistics 88: 510-530.

Meuleman B, Davidov E and Billiet J. (2009) Changing attitudes toward immigration in Europe, 2002-2007: A dynamic group conflict theory approach. Social science research 38: 352-365.

Oesch D. (2006) Redrawing the Class Map: Stratification and Institutions in Germany, Britain, Sweden and Switzerland, London, UK: Palgrave Macmillan.

Ortega F and Polavieja JG. (2012) Labor-market exposure as a determinant of attitudes toward immigration. Labour Economics 19: 298-311. 
Ottaviano GI and Peri G. (2012) Rethinking the effect of immigration on wages. Journal of the European Economic Association 10: 152-197.

Paas T and Halapuu V. (2012) Attitudes towards immigrants and the integration of ethnically diverse societies. Eastern Journal of European Studies 3: 161-176.

Pardos-Prado S and Xena C. (2018) Skill Specificity and Attitudes toward Immigration. American Journal of Political Science.

Pichler F. (2010) Foundations of anti-immigrant sentiment: The variable nature of perceived group threat across changing European societies, 2002-2006. International Journal of Comparative Sociology 51: 445-469.

Polavieja JG. (2016) Labour-market competition, recession and anti-immigrant sentiments in Europe: occupational and environmental drivers of competitive threat. SocioEconomic Review 14: 395-417.

Putnam RD. (2007) E pluribus unum: Diversity and community in the twenty-first century the 2006 Johan Skytte Prize Lecture. Scandinavian political studies 30: 137-174.

Rovny AE and Rovny J. (2017) Outsiders at the ballot box: operationalizations and political consequences of the insider-outsider dualism. Socio-Economic Review Online Early View.

Rueda D. (2007) Social Democracy Inside Out: Partisanship and Labor Market Policy in Industrialised Democracies, New York, NY: Oxford University Press.

Rustenbach E. (2010) Sources of negative attitudes toward immigrants in Europe: A multilevel analysis. International Migration Review 44: 53-77.

Scheve KF and Slaughter MJ. (2001) Labor market competition and individual preferences over immigration policy. Review of Economics and Statistics 83: 133-145. 
Schmidt-Catran AW and Fairbrother M. (2016) The Random Effects in Multilevel Models:

Getting Them Wrong and Getting Them Right. European Sociological Review 32: 2338.

Schneider SL. (2008) Anti-Immigrant Attitudes in Europe: Outgroup Size and Perceived Ethnic Threat. European Sociological Review 24: 53-67.

Schwander H and Häusermann S. (2013) Who is in and who is out? A risk-based conceptualization of insiders and outsiders. Journal of European Social Policy 23: 248-269.

Semyonov M, Raijman R and Gorodzeisky A. (2006) The rise of anti-foreigner sentiment in European societies, 1988-2000. American Sociological Review 71: 426-449.

Sides J and Citrin J. (2007) European Opinion about Immigration: The Role of Identities, Interests and Information. British Journal of Political Science 37: 477-504.

Sniderman PM and Hagendoorn L. (2007) When Ways of Life Collide, Princeton, NJ: Princeton University Press.

Vosko LF. (2009) Managing the margins: Gender, citizenship, and the international regulation of precarious employment: Oxford University Press.

Wilkes R, Guppy N and Farris L. (2008) "No Thanks, We're Full”: Individual Characteristics, National Context, and Changing Attitudes Toward Immigration. International Migration Review 42: 302-329.

Zolberg AR. (1991) Bounded states in a global market: The uses of international labor migrations. Social theory for a changing society: 301-325. 
Appendix Table 1: Countries included in regression analysis, with number of observations per wave. (Note that Austrian data from ESS wave 4 has been coded as 2010 due to fieldwork delays.)

\begin{tabular}{lccccc}
\hline & 2008 & 2010 & 2012 & 2014 & Total \\
\hline Austria & & 436 & & 707 & 1143 \\
Belgium & 879 & 821 & 972 & 901 & 3573 \\
Czech Republic & 749 & 822 & 636 & 769 & 2976 \\
Denmark & 805 & 865 & 898 & 867 & 3435 \\
Estonia & 637 & 772 & 899 & & 2308 \\
Finland & 1264 & 1040 & & 1125 & 3429 \\
France & 1050 & 889 & 937 & 974 & 3850 \\
Germany & & 1253 & 1343 & 1484 & 4080 \\
Greece & 614 & & & & 614 \\
Hungary & 436 & 572 & 576 & 529 & 2113 \\
Iceland & & & 398 & & 398 \\
Ireland & 843 & 821 & & 783 & 2447 \\
Italy & & & 315 & & 315 \\
Netherlands & 896 & 813 & 837 & 944 & 3490 \\
Norway & 1062 & 992 & 1075 & 915 & 4044 \\
Poland & 615 & 655 & 687 & 561 & 2518 \\
Portugal & 322 & & 376 & 494 & 1192 \\
Slovakia & & 465 & 586 & & 1051 \\
Slovenia & 399 & 387 & 359 & 358 & 1503 \\
Spain & 861 & 855 & & 770 & 2486 \\
Sweden & 1171 & 905 & 1057 & 1036 & 4169 \\
Switzerland & & 727 & 736 & 740 & 2203 \\
United Kingdom & 1065 & 962 & 812 & 875 & 3714 \\
& & & & & \\
\hline Total & 13668 & 15052 & 13499 & 14832 & 57051 \\
\hline
\end{tabular}


Appendix Table 2: Weighted descriptive statistics of main variables. (Note that there are 57051 observations in each instance.)

\begin{tabular}{|c|c|c|c|c|}
\hline & Mean & $\begin{array}{c}\text { Standard } \\
\text { Deviation }\end{array}$ & $\begin{array}{l}\text { Minimum } \\
\text { Value }\end{array}$ & $\begin{array}{l}\text { Maximum } \\
\text { Value }\end{array}$ \\
\hline $\begin{array}{l}\text { Immigrants improve } \\
\text { economy }\end{array}$ & 5.233 & 2.363 & 0 & 10 \\
\hline Outsiderness & -0.056 & 0.708 & -1.900 & 2.096 \\
\hline Education & 3.553 & 1.260 & 1 & 5 \\
\hline Income decile & 6.212 & 2.710 & 1 & 10 \\
\hline Household size & 3.027 & 1.357 & 1 & 15 \\
\hline Male & 0.535 & 0.499 & 0 & 1 \\
\hline Age & 41.748 & 12.400 & 15 & 123 \\
\hline Trade union member & 0.205 & 0.404 & 0 & 1 \\
\hline Unemployed & 0.083 & 0.277 & 0 & 1 \\
\hline Self employed & 0.121 & 0.326 & 0 & 1 \\
\hline Part-time employed & 0.211 & 0.408 & 0 & 1 \\
\hline Non-employed & 0.175 & 0.380 & 0 & 1 \\
\hline Self-identified minority & 0.049 & 0.216 & 0 & 1 \\
\hline City resident & 0.298 & 0.457 & 0 & 1 \\
\hline Religion & 0.768 & 0.892 & 0 & 3 \\
\hline Married & 0.556 & 0.497 & 0 & 1 \\
\hline Ideology & 4.892 & 2.094 & 0 & 10 \\
\hline $\begin{array}{l}\text { Change in GDP per } \\
\text { capita (PPP) }\end{array}$ & 1096.922 & 805.072 & -2521.637 & 5871.059 \\
\hline $\begin{array}{l}\text { Migrant stock ( } \% \text { of } \\
\text { pop.) }\end{array}$ & 11.266 & 4.453 & 1.616 & 28.810 \\
\hline $\begin{array}{l}\text { Skilled migrants ( } \% \text { of } \\
\text { migrants) }\end{array}$ & 28.979 & 8.563 & 11.400 & 50.600 \\
\hline GDP per capita (PPP) & 37949.130 & 8371.715 & 18315.130 & 66018.420 \\
\hline Unemployment rate & 8.546 & 4.147 & 2.500 & 24.400 \\
\hline
\end{tabular}


Appendix Table 3: Robustness checks

\begin{tabular}{|c|c|c|c|c|}
\hline & $\begin{array}{c}\text { Jackknife - } \\
\text { Individual-level } \\
\text { Model } \\
\end{array}$ & $\begin{array}{l}\text { Jackknife - Full } \\
\text { Model }\end{array}$ & $\begin{array}{c}\text { Cluster Robust } \\
\text { SEs }\end{array}$ & No Weights \\
\hline Outsiderness & $\begin{array}{c}-0.221^{* * *} \\
(0.052)\end{array}$ & $\begin{array}{c}0.174 \\
(0.292)\end{array}$ & $\begin{array}{c}0.174 \\
(0.137)\end{array}$ & $\begin{array}{c}0.127 \\
(0.086)\end{array}$ \\
\hline \multicolumn{5}{|l|}{$\begin{array}{l}\text { Education: baseline }-< \\
\text { lower secondary }\end{array}$} \\
\hline Lower secondary & $\begin{array}{c}0.166^{*} \\
(0.065)\end{array}$ & $\begin{array}{l}0.0944 \\
(0.111)\end{array}$ & $\begin{array}{l}0.0944 \\
(0.089)\end{array}$ & $\begin{array}{l}0.158^{* *} \\
(0.052)\end{array}$ \\
\hline Upper secondary & $\begin{array}{l}0.427^{* * *} \\
(0.068)\end{array}$ & $\begin{array}{l}0.331^{* *} \\
(0.098)\end{array}$ & $\begin{array}{l}0.331^{* * *} \\
(0.077)\end{array}$ & $\begin{array}{l}0.413^{* * *} \\
(0.050)\end{array}$ \\
\hline $\begin{array}{l}\text { Post-secondary non- } \\
\text { tertiary }\end{array}$ & $\begin{array}{l}0.615^{* * *} \\
(0.091)\end{array}$ & $\begin{array}{l}0.570^{* * * *} \\
(0.111)\end{array}$ & $\begin{array}{l}0.570^{* * * *} \\
(0.084)\end{array}$ & $\begin{array}{l}0.600^{* * *} \\
(0.061)\end{array}$ \\
\hline Tertiary education & $\begin{array}{l}1.238^{* * *} \\
(0.064)\end{array}$ & $\begin{array}{l}1.166^{* * *} \\
(0.062)\end{array}$ & $\begin{array}{l}1.166^{* * * *} \\
(0.048)\end{array}$ & $\begin{array}{l}1.224^{* * *} \\
(0.051)\end{array}$ \\
\hline Income decile & $\begin{array}{l}0.0627^{* * *} \\
(0.009)\end{array}$ & $\begin{array}{l}0.0765^{* * *} \\
(0.009)\end{array}$ & $\begin{array}{l}0.0765^{* * *} \\
(0.007)\end{array}$ & $\begin{array}{l}0.0652^{* * *} \\
(0.004)\end{array}$ \\
\hline Household size & $\begin{array}{c}-0.0484^{* * *} \\
(0.011)\end{array}$ & $\begin{array}{c}-0.0609^{* * *} \\
(0.012)\end{array}$ & $\begin{array}{c}-0.0609^{* * *} \\
(0.012)\end{array}$ & $\begin{array}{l}-0.0497^{* * *} \\
(0.008)\end{array}$ \\
\hline Male & $\begin{array}{c}0.161^{*} \\
(0.067)\end{array}$ & $\begin{array}{l}0.228^{*} \\
(0.094)\end{array}$ & $\begin{array}{l}0.228^{* *} \\
(0.083)\end{array}$ & $\begin{array}{l}0.137^{* * *} \\
(0.023)\end{array}$ \\
\hline Age & $\begin{array}{c}-0.00551 \\
(0.009)\end{array}$ & $\begin{array}{l}0.00332 \\
(0.014)\end{array}$ & $\begin{array}{l}0.00332 \\
(0.013)\end{array}$ & $\begin{array}{c}-0.00503 \\
(0.005)\end{array}$ \\
\hline Age \# Age & $\begin{array}{l}0.0000404 \\
(0.000)\end{array}$ & $\begin{array}{l}-0.0000620 \\
(0.000)\end{array}$ & $\begin{array}{l}-0.0000620 \\
(0.000)\end{array}$ & $\begin{array}{c}0.0000341 \\
(0.000)\end{array}$ \\
\hline Trade union member & $\begin{array}{l}-0.0312 \\
(0.039)\end{array}$ & $\begin{array}{l}0.0133 \\
(0.063)\end{array}$ & $\begin{array}{l}0.0133 \\
(0.055)\end{array}$ & $\begin{array}{l}-0.0356 \\
(0.023)\end{array}$ \\
\hline Unemployed & $\begin{array}{c}-0.197^{* * *} \\
(0.051)\end{array}$ & $\begin{array}{l}-0.115^{+} \\
(0.059)\end{array}$ & $\begin{array}{l}-0.115^{*} \\
(0.056)\end{array}$ & $\begin{array}{c}-0.181^{* * *} \\
(0.036)\end{array}$ \\
\hline Self employed & $\begin{array}{l}0.0394 \\
(0.038)\end{array}$ & $\begin{array}{l}0.0647 \\
(0.042)\end{array}$ & $\begin{array}{l}0.0647 \\
(0.040)\end{array}$ & $\begin{array}{l}0.0387 \\
(0.030)\end{array}$ \\
\hline Part-time employed & $\begin{array}{l}0.0703^{*} \\
(0.032)\end{array}$ & $\begin{array}{l}0.120^{* * *} \\
(0.037)\end{array}$ & $\begin{array}{l}0.120^{* * *} \\
(0.032)\end{array}$ & $\begin{array}{l}0.0890^{* * *} \\
(0.025)\end{array}$ \\
\hline Non-employed & $\begin{array}{l}0.238^{* * * *} \\
(0.045)\end{array}$ & $\begin{array}{l}0.266^{* * * *} \\
(0.068)\end{array}$ & $\begin{array}{l}0.266^{* * *} \\
(0.058)\end{array}$ & $\begin{array}{l}0.231^{* * *} \\
(0.024)\end{array}$ \\
\hline Self-identified minority & $\begin{array}{l}0.412^{* * * *} \\
(0.076)\end{array}$ & $\begin{array}{l}0.464^{*} \\
(0.177)\end{array}$ & $\begin{array}{l}0.464^{* *} \\
(0.143)\end{array}$ & $\begin{array}{l}0.411^{* * *} \\
(0.045)\end{array}$ \\
\hline City resident & $\begin{array}{l}0.300^{* * * *} \\
(0.035)\end{array}$ & $\begin{array}{l}0.305^{* * *} \\
(0.037)\end{array}$ & $\begin{array}{l}0.305^{* * * *} \\
(0.033)\end{array}$ & $\begin{array}{l}0.298^{* * *} \\
(0.020)\end{array}$ \\
\hline Married & $\begin{array}{l}0.0436 \\
(0.037)\end{array}$ & $\begin{array}{c}0.00743 \\
(0.029)\end{array}$ & $\begin{array}{c}0.00743 \\
(0.027)\end{array}$ & $\begin{array}{l}0.0315 \\
(0.022)\end{array}$ \\
\hline $\begin{array}{l}\text { Religion: baseline - } \\
\text { none }\end{array}$ & & & & \\
\hline Catholic & $\begin{array}{c}-0.0614 \\
(0.084)\end{array}$ & $\begin{array}{c}-0.0508 \\
(0.111)\end{array}$ & $\begin{array}{c}-0.0508 \\
(0.100)\end{array}$ & $\begin{array}{c}-0.0666^{*} \\
(0.026)\end{array}$ \\
\hline Protestant & $\begin{array}{l}0.0198 \\
(0.061)\end{array}$ & $\begin{array}{c}-0.00307 \\
(0.150)\end{array}$ & $\begin{array}{c}-0.00307 \\
(0.105)\end{array}$ & $\begin{array}{l}0.0212 \\
(0.028)\end{array}$ \\
\hline Other & $\begin{array}{l}0.370^{* *} \\
(0.098)\end{array}$ & $\begin{array}{l}0.505^{* *} \\
(0.134)\end{array}$ & $\begin{array}{l}0.505^{* * *} \\
(0.109)\end{array}$ & $\begin{array}{l}0.362^{* * *} \\
(0.045)\end{array}$ \\
\hline Ideology & $\begin{array}{c}-0.103^{* * * *} \\
(0.026)\end{array}$ & $\begin{array}{l}-0.140^{* *} \\
(0.042)\end{array}$ & $\begin{array}{c}-0.140^{* * * *} \\
(0.035)\end{array}$ & $\begin{array}{c}-0.103^{* * *} \\
(0.004)\end{array}$ \\
\hline
\end{tabular}


Survey Wave: Baseline

$$
-2008
$$

2010

$$
-0.134^{+}
$$

$-0.0107$

$-0.0107$

$-0.0255$

2012

$(0.078)$

$(0.116)$

(0.093)

$(0.092)$

$-0.0479$

0.0172

0.0172

0.0122

2014

(0.068)

$(0.132)$

(0.107)

(0.110)

$-0.199^{*}$

$-0.164$

$-0.164$

$-0.223^{+}$

GDP per capita

(0.087)

(0.168)

0.0000179

(0.142)

(0.128)

$(0.000)$

$-0.00001$

Outsiderness \# GDP

per capita

Unemployment rate

$(0.000)$

$-0.0256$

(0.026)

Outsiderness \#

Unemployment rate

0.000594

0.0000179

0.0000230

$(0.000)$

$-0.00001^{* *}$

(0.000)

$(0.000)$

Change in GDP per

$(0.009)$

$-0.0256$

(0.017)

$-0.000009^{* * *}$

capita

Migrant stock (\% of

0.0000509

0.000594

$(0.000)$

$-0.0179$

$(0.000)$

0.0297

(0.005)

(0.016)

$-0.0000862$

$(0.021)$

$-0.00946$

$0.0000509^{*}$

$(0.003)$

pop.)

Skilled migrants (\% of

(0.013)

migrants)

Constant

$4.740^{* * *}$

$4.030^{* * *}$

(0.000)

$0.0297^{+}$

0.0000321

(0.000)

(0.018)

0.0192

$-0.00946$

$(0.025)$

(0.009)

$4.030^{* * *}$

$-0.00689$

(0.161)

$(0.689)$

\begin{tabular}{|c|c|c|c|c|}
\hline \multicolumn{2}{|l|}{$\begin{array}{l}\text { Variances } \\
\text { Country }\end{array}$} & $\begin{array}{c}0.600 \\
(0.195)\end{array}$ & $\begin{array}{c}0.600^{*} \\
(0.151)\end{array}$ & $\begin{array}{l}0.565^{* * * *} \\
(0.092)\end{array}$ \\
\hline Country-year & & $\begin{array}{c}0.157^{* * *} \\
(0.026)\end{array}$ & $\begin{array}{c}0.157^{* * *} \\
(0.020)\end{array}$ & $\begin{array}{c}0.174^{* * *} \\
(0.022)\end{array}$ \\
\hline Residual & & $\begin{array}{c}2.177^{* * *} \\
(0.033)\end{array}$ & $\begin{array}{c}2.177^{* * * *} \\
(0.031)\end{array}$ & $\begin{array}{c}2.132^{* * * *} \\
(0.006)\end{array}$ \\
\hline Observations & 57051 & 57051 & 57051 & 57051 \\
\hline Country-years & 72 & 72 & 72 & 72 \\
\hline Countries & 23 & 23 & 23 & 23 \\
\hline
\end{tabular}

(0.589)

Standard errors in parentheses

${ }^{+} p<0.10,{ }^{*} p<0.05,{ }^{* *} p<0.01,{ }^{* * *} p<0.001$ 